Bożena BABIARZ

Barbara ZIĘBA

Politechnika Rzeszowska

\title{
ANALIZA JEDNOSTKOWYCH STRAT CIEPLA W SYSTEMIE RUR PREIZOLOWANYCH
}

\begin{abstract}
$\mathrm{W}$ artykule przedstawiono analizę jednostkowych strat ciepła w wyniku przenikania dla sieci ciepłowniczej preizolowanej. Obliczono jednostkowe straty ciepła dla trzech najczęściej stosowanych wariantów izolacji systemu pary rur pojedynczych oraz dla systemu TwinPipe. Dokonano porównania wielkości strat dla rozpatrywanych wariantów.
\end{abstract}

Słowa kluczowe: preizolowane rury, warianty izolacji systemu oraz analiza porównawcza, jednostkowe straty ciepła

\section{Wprowadzenie}

Duże straty ciepła podczas przesyłu, jak również awaryjność sieci ciepłowniczych tradycyjnych przyczyniły się w znacznym stopniu do rozwoju technologii rur preizolowanych. Preizolowane sieci ciepłownicze są stosowane na świecie od początku lat siedemdziesiątych ubiegłego wieku. W Polsce rury preizolowane zaczęto stosować na dużą skalę od 1989 roku [1]. Rury preizolowane przygotowuje się fabrycznie do układania w wykopie lub kanale, bez konieczności wykonywania dodatkowych prac izolacyjnych, z wyjątkiem izolowania złączy i armatury. Technologia rur preizolowanych posiada wiele zalet, do których należą m.in. [2]:

- wysoka jakość i trwałość izolacji; proces izolowania powierzchni rur odbywa się w ściśle określonych warunkach w zakładach przemysłowych,

- możliwość układania rur bezpośrednio w gruncie,

- mniejsza pracochłonność robót wykonawczych na placu budowy,

- mniejsze wymiary wykopów ziemnych,

- szybsza realizacja inwestycji,

- mniejsze koszty budowy sieci cieplnych,

- możliwość prowadzenia stałego nadzoru stanu instalacji rurociagów dzięki instalacji alarmowej [3].

Pierwsze rury preizolowane posiadały izolację ze sztywnego krzemianu wapnia, którą wykonywano technologią stosunkowo drogą i skomplikowaną. 
W latach siedemdziesiątych XX wieku opracowano technologię rur preizolowanych z izolacją z pianobetonu. Metoda ta była skutecznie stosowana przez dwadzieścia lat. Wykorzystywane wtedy materiały izolacyjne charakteryzowały się dość dużą kruchością, co stanowiło problem podczas transportu oraz magazynowania rur preizolowanych. Nie mniejsze utrudnienia występowały na placu budowy, gdzie wiele rur zostało uszkodzonych oraz podczas ich eksploatacji. $\mathrm{W}$ związku z tym prowadzono badania nad nowymi materiałami izolacyjnymi spełniającymi wymagania stawiane izolacjom cieplnym i przeciwwilgociowym przewodów, uwzględniając ich trwałość i wytrzymałość mechaniczną. Przełomem w technologii rur okazało się zastosowanie polimerów jako izolacji. Od lat dziewięćdziesiątych stosuje się rury preizolowane układane bezpośrednio $\mathrm{w}$ gruncie, gdzie izolacją jest sztywna pianka poliuretanowa.

\section{Uwarunkowania strat ciepła w rurach preizolowanych}

Budowę rury preizolowanej obrazuje rys. 1. Rura preizolowana składa się z takich elementów, jak: rura właściwa, izolacja, rura osłonowa i przewody alarmowe umieszczone w warstwie izolacyjnej.

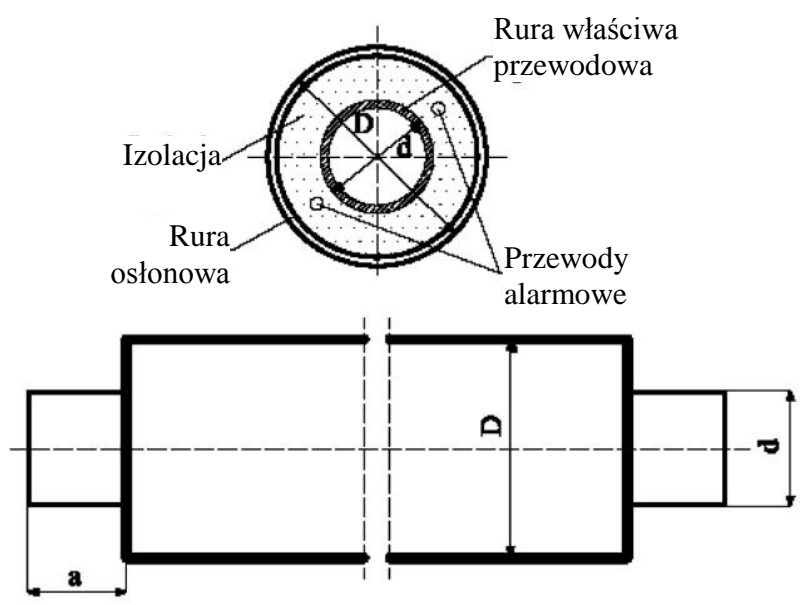

Rys. 1. Konstrukcja rur preizolowanych

W sieciach ciepłowniczych występują straty:

- związane z wymianą ciepła,

- spowodowane ubytkami (wyciekami) wody sieciowej.

Straty związane z wymianą ciepła stanowią główne źródło całkowitych strat ciepła. Ubytki wody sieciowej powodują znacznie mniejsze straty ciepła, ich udział w całkowitych stratach ciepła nie przekracza 20\% [4]. 
Straty wynikające z wymiany ciepła zależą od wielu czynników i znacznie się różnią w poszczególnych systemach ciepłowniczych. Nowe sieci wykonane z rur preizolowanych i prawidłowo eksploatowane cechują straty na poziomie $6 \div 7 \%$ (średniorocznie). W przypadku starszych sieci wykonanych w technologii kanałowej i zaizolowanych wełną mineralną udział strat ciepła osiaga kilkanaście procent, a w skrajnych przypadkach (duże zawilgocenie izolacji) może wynosić nawet ok. $20 \%$ w sezonie i $50 \%$ w lecie [4].

$\mathrm{Na}$ straty ciepła w sieciach ciepłowniczych wpływa wiele czynników. Każda technologia charakteryzuje się projektowym średniorocznym poziomem strat ciepła.

Istotny wpływ na straty ciepła ma izolacja cieplna przewodu. Izolacja cieplna oprócz ochrony przed stratami powinna zapobiegać przenikaniu wilgoci i chronić przed uszkodzeniami mechanicznymi.

Dobra izolacja przewodów cieplnych powinna cechować się:

- odpornością na działanie wysokiej temperatury,

- małą wartością współczynnika przewodzenia ciepła,

- odpornością na zawilgocenie (właściwości hydrofobowe),

- odpornością na uszkodzenia mechaniczne,

- łatwością wykonania i naprawy,

- brakiem oddziaływania swojej wewnętrznej warstwy na ściankę rury [2].

Duży wpływ na straty ciepła ma jakość elementów sieci, dokładność montażu oraz warunki eksploatacyjne. Dobrze wykonane spawy zapobiegają nieszczelnościom i wyciekom wody sieciowej. Odpowiednio zamontowane mufy uniemożliwiają przedostawanie się wilgoci do warstwy izolacyjnej, co zapobiega pogorszeniu właściwości izolacyjnych. Nie wolno zapominać, że w okresie eksploatacyjnym właściwości izolacji cieplnej pogarszają się ze względu na wilgoć i wysoką temperaturę. Ważnym aspektem jest jakość wody sieciowej. Zły stan wody sieciowej prowadzi do szybkiej korozji przewodów, będącej przyczyną ubytków czynnika grzewczego i awarii.

\section{Metodyka obliczeń stosowana w programie do obliczania strat ciepla w systemie rur preizolowanych}

\subsection{Obliczenia strat ciepla pary rur pojedynczych}

Opór cieplny izolacji dla $1 \mathrm{~m}$ długości układu (rys. 2.):

$$
R_{i}=\frac{1}{2 \cdot \pi \cdot \lambda_{i}} \cdot \ln \frac{D_{\mathrm{PUR}}}{d_{o}}[\mathrm{mK} / \mathrm{W}]
$$

gdzie: $D_{P U R}-$ średnica zewnętrzna materiału izolacyjnego, $D_{\mathrm{PUR}}=D_{C}-2 g_{c}$ $[\mathrm{m}]$, 
$d_{o}$ - średnica zewnętrzna rury przewodowej [m],

$\lambda_{i}-$ współczynnik przewodności cieplnej dla izolacji $\lambda_{50}$ deklarowany przez producenta rur $[\mathrm{W} / \mathrm{mK}]$.

Opór cieplny gruntu:

$$
R_{s}=\frac{1}{2 \cdot \pi \cdot \lambda_{s}} \ln \frac{4 \cdot Z_{c}}{D_{c}}[\mathrm{mK} / \mathrm{W}]
$$

gdzie: $D_{c}$ - średnica zewnętrzna płaszcza osłonowego [m],

$\lambda_{s}$ - współczynnik przewodzenia ciepła gruntu, dla mokrego gruntu można zwykle przyjąć od 1,5 W/mK do $2 \mathrm{~W} / \mathrm{mK}$, dla suchego piasku $\lambda_{s} \approx 1,0 \mathrm{~W} / \mathrm{mK}$,

$Z_{c}$ - skorygowana wartość głębokości $Z \mathrm{w}$ celu uwzględnienia przejściowej zdolności izolacyjnej powierzchni $R_{o}$ na powierzchni gruntu, $Z_{c}=Z+R_{o} \cdot \lambda_{s}$, przy czym $Z$ - odległość od powierzchni do osi rury, $Z=H+\frac{D_{c}}{2}[m], R_{o}-$ można zwykle przyjaćc $0,0685 \mathrm{mK} / \mathrm{W}$.

Wymiana ciepła między rurociągiem zasilającym a powrotnym:

$$
R_{h}=\frac{1}{4 \cdot \pi \cdot \lambda_{s}} \cdot \ln \left(1+\left(\frac{2 \cdot Z_{c}}{C}\right)^{2}\right)[\mathrm{mK} / \mathrm{W}]
$$

gdzie $C$ - odległość między osiami rurociagów [m].

Współczynniki strat ciepła rurociagów zasilającego (1) i powrotnego (2):

$$
\begin{aligned}
& U_{1}=\frac{R_{s}+R_{i}}{\left(R_{s}+R_{i}\right)^{2}-R_{h}^{2}}[\mathrm{~W} / \mathrm{mK}] \\
& U_{2}=\frac{R_{h}}{\left(R_{s}+R_{i}\right)^{2}-R_{h}^{2}}[\mathrm{~W} / \mathrm{mK}]
\end{aligned}
$$

gdzie: $R_{s}$ - jednostkowy opór cieplny przewodzenia gruntu [mK/W],

$R_{i}$ - jednostkowy opór cieplny przewodzenia izolacji [mK/W],

$R_{h}$ - opór cieplny od wzajemnego oddziaływania rurociągów zasilającego i powrotnego [mK/W].

Jednostkowe straty ciepła pary rur preizolowanych w gruncie:

$$
q=\left(U_{1}-U_{2}\right) \cdot\left(t_{1 s r}+t_{2 s r}-2 \cdot t_{s}\right)=U \cdot\left(t_{1 s r}+t_{2 s r}-2 \cdot t_{s}\right)[\mathrm{W} / \mathrm{m}]
$$


gdzie: $t_{1 s r}$ - średnia temperatura zasilania w okresie grzewczym / poza okresem $\left[{ }^{\circ} \mathrm{C}\right]$,

$t_{2 s r}$ - średnia temperatura powrotu $\mathrm{w}$ okresie grzewczym / poza okresem $\left[{ }^{\circ} \mathrm{C}\right]$,

$t_{s}$ - średnia temperatura gruntu $\left[{ }^{\circ} \mathrm{C}\right]$.

\subsection{Obliczenia strat ciepla dla rur TwinPipe}

Obliczanie strat ciepła dla systemu TwinPipe opiera się na metodzie multipolowej wykorzystującej zasadę superpozycji stanów symetrycznego i asymetrycznego.

Temperatura rury:

- stan symetryczny

$$
t_{s m}=\frac{t_{f}+t_{r}}{2}\left[{ }^{\circ} \mathrm{C}\right]
$$

gdzie: $t_{f}$ - średnia temperatura $\mathrm{w}$ przewodzie zasilającym $\mathrm{w}$ stanie symetrycznym $\left[{ }^{\circ} \mathrm{C}\right]$,

$t_{r}$ - średnia temperatura $\mathrm{w}$ przewodzie powrotnym $\mathrm{w}$ stanie symetrycznym $\left[{ }^{\circ} \mathrm{C}\right]$,

- stan asymetryczny

$$
t_{a}=\frac{t_{f}-t_{r}}{2}\left[{ }^{\circ} \mathrm{C}\right]
$$

przy czym oznaczenia przyjęto jak we wzorze (7).

Składowa strat ciepła:

- stan symetryczny

$$
q_{s}=\left(t_{s m}-t_{s}\right) \cdot 2 \cdot \pi \cdot \lambda_{i} \cdot h_{s}[\mathrm{~W} / \mathrm{m}]
$$

gdzie: $t_{s m}$ - temperatura czynnika w przewodzie w stanie symetrycznym $\left[{ }^{\circ} \mathrm{C}\right]$,

$t_{s}$ - temperatura gruntu $\left[{ }^{\circ} \mathrm{C}\right]$,

$\lambda_{i}-$ współczynnik przewodzenia ciepła izolacji $\lambda_{50}$ (wg PN-EN 253 [5]) deklarowany przez producenta rur $[\mathrm{W} / \mathrm{mK}]$,

$h_{s}$ - współczynnik strat ciepła dla stanu symetrycznego,

- stan asymetryczny

$$
q_{a}=t_{a} \cdot 2 \cdot \pi \cdot \lambda_{i} \cdot h_{a}[\mathrm{~W} / \mathrm{m}]
$$

gdzie $h_{a}$ - współczynnik strat ciepła dla stanu asymetrycznego. 
Jednostkowe straty ciepła rurociągów:

- zasilanie

$$
q_{1}=q_{s}+q_{a}[\mathrm{~W} / \mathrm{m}]
$$

- powrót

$$
q_{2}=q_{s}-q_{a}[\mathrm{~W} / \mathrm{m}]
$$

gdzie: $q_{s}$ - składowa strat ciepła w stanie symetrycznym $[\mathrm{W} / \mathrm{m}]$,

$q_{a}-$ składowa strat ciepła w stanie asymetrycznym $[\mathrm{W} / \mathrm{m}]$.

Sumaryczne straty ciepła rury preizolowanej TwinPipe:

$$
q_{1}+q_{2}=2 \cdot q_{s}[\mathrm{~W} / \mathrm{m}]
$$

Dla przybliżenia pierwszego rzędu

Współczynnik strat ciepła dla stanu symetrycznego $h_{s}$ :

$$
\begin{aligned}
h_{s}^{-1}= & 2 \cdot \frac{\lambda_{i}}{\lambda_{s}} \cdot \ln \left(\frac{4 \cdot Z}{D_{i}}\right)+\ln \left(\frac{D_{i}^{2}}{2 \cdot C \cdot d_{o}}\right)+ \\
& +\sigma \cdot \ln \left(\frac{D_{i}^{4}}{D_{i}^{4}-C^{4}}\right)-\frac{\left(\frac{d_{o}}{2 \cdot C}-\frac{2 \cdot \sigma \cdot d_{o} \cdot C^{3}}{D_{i}^{4}-C^{4}}\right)}{1+\left(\frac{d_{0}}{2 \cdot C}\right)^{2}+\sigma \cdot\left(\frac{2 \cdot d_{o} \cdot D_{i}^{2} \cdot C}{D_{i}^{4}-C^{4}}\right)^{2}}
\end{aligned}
$$

gdzie: $\lambda_{i}-$ współczynnik przewodzenia ciepła izolacji $\lambda_{50}$ (wg PN-EN 253) deklarowany przez producenta rur [W/mK],

$\lambda_{s}$ - współczynnik przewodzenia ciepła gruntu $\left(\lambda_{s}=1,0 \mathrm{~W} / \mathrm{mK}-\right.$ grunt suchy, $\lambda_{s}=1,6 \mathrm{~W} / \mathrm{mK}-$ grunt średnio wilgotny, $\lambda_{s}=2,0 \mathrm{~W} / \mathrm{mK}-$ grunt mokry) $[\mathrm{W} / \mathrm{mK}]$,

$d_{o}$ - średnica zewnętrzna rury przewodowej $[\mathrm{m}]$,

$D_{i}$ - średnica zewnętrzna izolacji [m],

$Z$ - odległość od średnicy rury przewodowej do powierzchni gruntu

$$
Z=H+\frac{D_{c}}{2}[\mathrm{~m}]
$$


$D_{c}$ - średnica zewnętrzna płaszcza osłonowego [m],

$C$ - odległość pomiędzy osiami rur przewodowych [m],

$\sigma$ - współczynnik izolacyjności.

Współczynnik izolacyjności można wyznaczyć z zależności:

$\sigma=\frac{\lambda_{i}-\lambda_{s}}{\lambda_{i}+\lambda_{s}}$

Współczynnik strat ciepła dla stanu asymetrycznego $h_{a}$ :

$$
\begin{aligned}
h_{a}^{-1}= & \ln \left(\frac{2 \cdot C}{d_{o}}\right)+\sigma \cdot \ln \left(\frac{D_{i}^{2}+C^{2}}{D_{i}^{2}-C^{2}}\right)- \\
& +\frac{\left(\frac{d_{o}}{2 \cdot C}-\gamma \cdot \frac{C \cdot d_{o}}{16 \cdot Z^{2}} \frac{2 \cdot \sigma \cdot d_{o} \cdot D_{i}^{2} \cdot C}{D_{i}^{4}-C^{4}}\right)}{1-\left(\frac{d_{o}}{2 \cdot C}\right)^{2}-\frac{d_{o}}{4 \cdot Z}+2 \cdot \sigma \cdot d_{o}^{2} \cdot D_{i}^{2} \cdot \frac{D_{i}^{4}+C^{4}}{D_{i}^{4}-C^{4}}}-\gamma \cdot\left(\frac{C}{4 \cdot Z}\right)^{2}
\end{aligned}
$$

gdzie $\gamma$-współczynnik pomocniczy.

Współczynnik pomocniczy wyznacza się z następującej zależności:

$$
\gamma=\frac{2 \cdot\left(1-\sigma^{2}\right)}{1-\sigma\left(\frac{D_{i}}{4 \cdot Z}\right)^{2}}
$$

\section{Obliczenia strat ciepla w systemie rur preizolowanych}

\subsection{Założenia do obliczeń}

W celu wykonania analizy porównawczej strat ciepła w systemie rur preizolowanych rozpatrzono różne warianty grubości izolacji cieplnej przewodów preizolowanych. Założono, że sieć ciepłownicza podziemna bezkanałowa jest nowa i całkowicie szczelna, nie ma więc konieczności kalkulowania strat ciepła powodowanych przez starzejącą się izolację oraz ubytki nośnika energii cieplnej. 

izolacji:

Rozpatrzono cztery warianty odcinków sieci cieplnej różniące się grubością

1) S-S - typowe i najczęściej stosowane rozwiązanie, a mianowicie przewody zasilający i powrotny są zaizolowane standardową (Standard) izolacją cieplnac,

2) P-S - straty ciepła obliczone dla przewodu zasilającego z izolacją pogrubioną (Plus) i powrotnego z izolacją standardową (Standard),

3) P-P - przedstawia straty ciepła na przewodach zasilającym i powrotnym $\mathrm{z}$ izolacją pogrubioną (Plus),

4) straty ciepła na odcinku sieci dla systemu rur TwinPipe.

Obliczenia wykonano wg PN-EN:15968 dla systemu rur preizolowanych w programie przeznaczonym do obliczeń sieci ciepłowniczych, dostępnym na stronie internetowej [6]. Rura przewodowa jest wykonana ze stali ze szwem wzdłużnym lub ze szwem spiralnym. Współczynnik przewodzenia ciepła izolacji PUR udokumentowany przez producenta systemu rur (badania wg PN-EN 253:2006) $\lambda_{i}=0,0257 \mathrm{~W} / \mathrm{mK}$. Izolacja jest wykonana $\mathrm{z}$ pianki poliuretanowej zagęszczonej cyklopentanem. Rury są produkowane w sposób tradycyjny, a płaszcz osłonowy jest wykonany z PEHD. W przypadku pierwszych trzech wariantów obliczenia zostały wykonane dla przewodów o średnicach nominalnych DN 32, DN 100, DN 300, natomiast dla wariantu czwartego wykonano obliczenia dla średnic DN 32 i DN 100.

Dane ogólne przyjęte do obliczeń:

- czas trwania sezonu grzewczego - 255 dni,

- średnia temperatura zasilania $\mathrm{w}$ sezonie grzewczym $-t_{f}=90^{\circ} \mathrm{C}$,

- średnia temperatura powrotu w sezonie grzewczym $-t_{r}=50^{\circ} \mathrm{C}$,

- temperatura gruntu $-t_{s}=8^{\circ} \mathrm{C}$,

- współczynnik przewodzenia ciepła gruntu $-\lambda_{s}=1,8 \mathrm{~W} / \mathrm{mK}$,

- przykrycie rurociagu gruntem $-H=1,0 \mathrm{~m}$,

- odległość pomiędzy płaszczami rur $-A=0,25 \mathrm{~m}$.

\subsection{Straty ciepła dla pary rur pojedynczych - warianty 1-3.}

Obliczenia strat ciepła wykonano zgodnie z modelem obliczeniowym dla pary rur preizolowanych pojedynczych (rys. 2.) oraz według PN-EN:13941 [7]. System pary rur pojedynczych jest najczęściej stosowanym systemem w nowoczesnych sieciach ciepłowniczych.

Wyniki obliczeń strat ciepła dla wariantu pierwszego S-S, gdzie przewód zasilający (indeks 1) i przewód powrotny (indeks 2) mają izolację standardową, przedstawiono $\mathrm{w}$ tab. 1 . W tabeli 2 . zestawiono wyniki obliczeń strat ciepła dla wariantu drugiego P-S dla średnic DN 32, DN 100 i DN 300, które mają izolację pogrubioną na zasilaniu, a standardową na powrocie. 


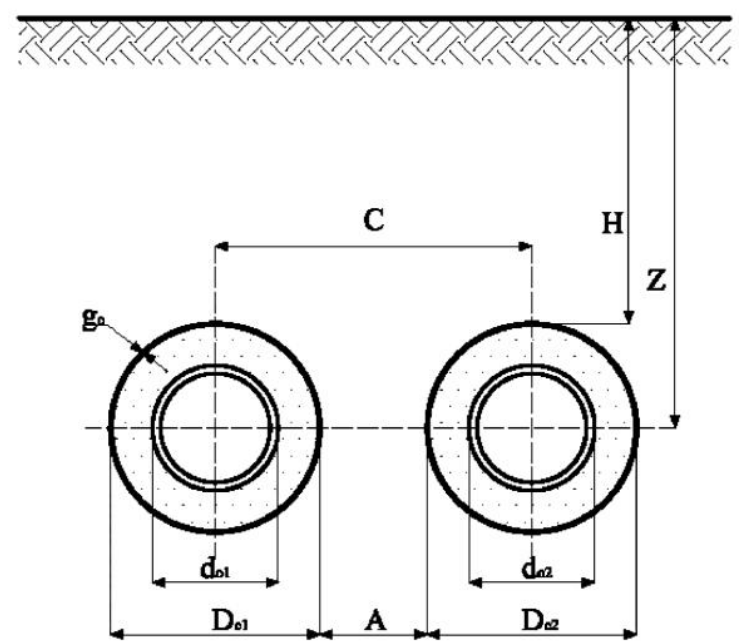

Rys. 2. Model obliczeniowy dla pary przewodów pojedynczych sieci ciepłowniczej preizolowanej; $d_{o}$ - średnica zewnętrzna rury przewodowej, $D_{c}$ - średnica zewnętrzna płaszcza osłonowego, $H$ - przykrycie rury gruntem, $A$ - odległość między płaszczami osłonowymi rur, $C$ - odległość pomiędzy osiami przewodu zasilającego i powrotnego, $g_{c}-$ grubość ścianki płaszcza osłonowego PEHD, $Z$ - odległość od powierzchni do osi rury

Tabela 1. Zestawienie wyników obliczeń dla wariantu pierwszego S-S dla średnic nominalnych DN 32, DN 100, DN 300

\begin{tabular}{|c|c|c|c|c|}
\hline Wspólczynnik & Jednostka & DN 32 & DN 100 & DN 300 \\
\hline $\boldsymbol{U}_{\mathbf{1}}$ & {$[\mathrm{W} / \mathrm{mK}]$} & 0,1798 & 0,2975 & 0,1222 \\
\hline $\boldsymbol{U}_{\mathbf{2}}$ & {$[\mathrm{W} / \mathrm{mK}]$} & 0,0054 & 0,0134 & 0,0302 \\
\hline $\boldsymbol{q}_{\mathbf{1}}$ & {$[\mathrm{W} / \mathrm{m}]$} & 14,5205 & 23,8323 & 39,6789 \\
\hline $\boldsymbol{q}_{\mathbf{2}}$ & {$[\mathrm{W} / \mathrm{m}]$} & 7,1106 & 11,3988 & 18,4530 \\
\hline $\boldsymbol{q}$ & {$[\mathrm{W} / \mathrm{m}]$} & $\mathbf{2 1 , 6 3}$ & $\mathbf{3 5 , 2 3}$ & $\mathbf{5 8 , 0 5}$ \\
\hline
\end{tabular}

Tabela 2. Zestawienie wyników obliczeń dla wariantu drugiego P-S dla średnic nominalnych DN 32, DN 100, DN 300

\begin{tabular}{|c|c|c|c|c|c|c|c|}
\hline Wspólczynnik & Jednostka & \multicolumn{2}{|c|}{ DN 32 } & \multicolumn{2}{c|}{ DN 100 } & \multicolumn{2}{c|}{ DN 300 } \\
\hline Rodzaj izolacji & & $\mathbf{S}$ & $\mathbf{P}$ & $\mathbf{S}$ & $\mathbf{P}$ & $\mathbf{S}$ & P \\
\hline $\boldsymbol{U}_{\mathbf{1}}$ & {$[\mathrm{W} / \mathrm{mK}]$} & 0,1789 & 0,1580 & 0,2975 & 0,2472 & 0,1222 & 0,3819 \\
\hline $\boldsymbol{U}_{\mathbf{2}}$ & {$[\mathrm{W} / \mathrm{mK}]$} & 0,0054 & 0,0041 & 0,0134 & 0,0090 & 0,0302 & 0,0172 \\
\hline $\boldsymbol{q}_{\mathbf{1}}$ & {$[\mathrm{W} / \mathrm{m}]$} & 14,5205 & 12,7824 & 23,8323 & 19,8928 & 39,6789 & 30,5972 \\
\hline $\boldsymbol{q}_{\mathbf{2}}$ & {$[\mathrm{W} / \mathrm{m}]$} & 7,1106 & 6,2993 & 11,3988 & 9,6445 & 18,4530 & 14,6326 \\
\hline $\boldsymbol{q}$ & {$[\mathrm{W} / \mathrm{m}]$} & \multicolumn{2}{|c|}{$\mathbf{1 9 , 8 9}$} & \multicolumn{2}{|c|}{$\mathbf{3 1 , 2 9 1 6}$} & \multicolumn{2}{|c|}{$\mathbf{4 9 , 0 5}$} \\
\hline
\end{tabular}


Tabela 3. zawiera zestawienie wyników obliczeń strat ciepła dla wariantu trzeciego P-P, gdzie średnice DN 32, DN 100 i DN 300 mają pogrubioną izolację zarówno na zasilaniu, jak i na powrocie.

Tabela 3. Zestawienie wyników obliczeń dla wariantu trzeciego P-P dla średnic DN 32, DN 100, DN 300

\begin{tabular}{|c|c|c|c|c|}
\hline Współczynnik & Jednostka & DN 32 & DN 100 & DN 300 \\
\hline $\boldsymbol{U}_{\mathbf{1}}$ & {$[\mathrm{W} / \mathrm{mK}]$} & 0,1580 & 0,2472 & 0,3819 \\
\hline $\boldsymbol{U}_{\mathbf{2}}$ & {$[\mathrm{W} / \mathrm{mK}]$} & 0,0041 & 0,0090 & 0,0172 \\
\hline $\boldsymbol{q}_{\mathbf{1}}$ & {$[\mathrm{W} / \mathrm{m}]$} & 12,7824 & 19,8928 & 30,5972 \\
\hline $\boldsymbol{q}_{\mathbf{2}}$ & {$[\mathrm{W} / \mathrm{m}]$} & 6,2993 & 9,6445 & 14,6326 \\
\hline $\boldsymbol{q}$ & {$[\mathrm{W} / \mathrm{m}]$} & $\mathbf{1 9 , 0 8}$ & $\mathbf{2 9 , 5 4}$ & $\mathbf{4 5 , 2 3}$ \\
\hline
\end{tabular}

\subsection{Straty ciepła dla systemu rur TwinPipe - wariant 4 .}

System rur preizolowanych TwinPipe to system rur, w którym w jednym płaszczu ochronnym są prowadzone dwa przewody (rys. 3.).

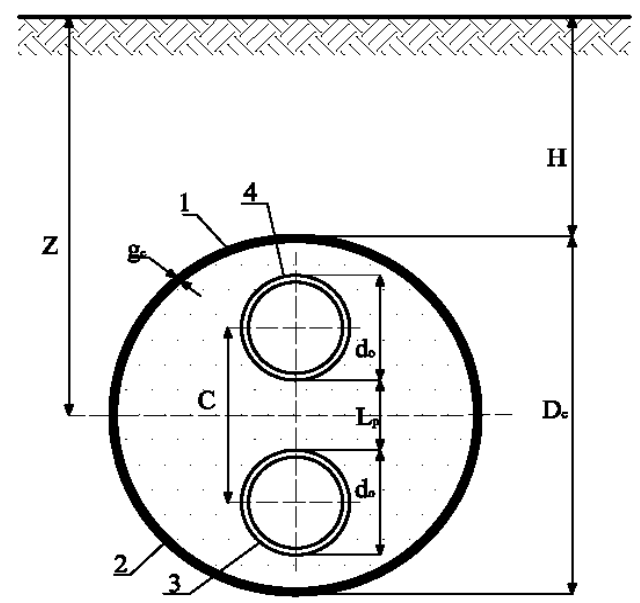

Rys. 3. Model obliczeniowy systemu rur preizolowanych TwinPipe; 1 - płaszcz zewnętrzny, 2 - izolacja PUR, 3 - rura przewodowa zasilająca (dolna), 4 - rura przewodowa powrotna (górna), $d_{o}$ - średnica zewnętrzna rury przewodowej, $D_{c}$ - średnica zewnętrzna płaszcza osłonowego, $H$ - przykrycie rury gruntem, $C$ - odległość między osiami przewodu zasilającego i powrotnego (zależne od $L_{p}$ wg [8]), $L_{p}$ - odległość między rurami przewodowymi (zależne od $d_{o}$ wg [8]), $g_{c}-$ grubość ścianki płaszcza osłonowego PEHD, $\mathrm{Z}$ - odległość od powierzchni do osi rury 
W normie [8] model obliczeniowy jest przedstawiony tzw. multipolową metodą przybliżoną pierwszego rzędu. W modelu tym pomija się opór cieplny rury stalowej oraz opór płaszcza osłonowego PEHD, które mają niewielki wpływ na wyniki obliczeń strat ciepła [9]. Wyniki obliczeń strat ciepła dla sieci cieplnej podziemnej bezkanałowej wykonanej w systemie TwinPipe zestawiono w tab. 4.

Tabela 4. Zestawienie wyników obliczeń strat ciepła systemu rur preizolowanych TwinPipe w programie do obliczeń sieci ciepłowniczych

\begin{tabular}{|c|c|c|}
\hline Współczynnik & DN 32 & DN 100 \\
\hline $\begin{array}{c}\text { Jednostkowa strata ciepła } \\
\boldsymbol{q}[\mathbf{W} / \mathbf{m}]\end{array}$ & $\mathbf{1 4 , 4}$ & $\mathbf{2 3 , 3}$ \\
\hline $\begin{array}{c}\text { Współczynnik strat ciepła } \\
\boldsymbol{U}[\mathbf{W} / \mathbf{m K}]\end{array}$ & 0,225 & 0,350 \\
\hline
\end{tabular}

Jednostkowe straty na przewodach TwinPipe wynoszą odpowiednio dla DN $32-14,4 \mathrm{~W} / \mathrm{m}$, dla DN $100-23,3 \mathrm{~W} / \mathrm{m}$.

\section{Analiza porównawcza wyników obliczeń strat ciepła}

Dla poszczególnych wariantów wyznaczono i porównano jednostkowe straty ciepła $\mathrm{w}$ odniesieniu do analizowanych średnic przewodów. System rur preizolowanych pojedynczych z izolacją standardową jest najczęściej stosowanym rozwiązaniem, ale powoli zaczyna być zastępowany systemem przewodów z izolacją pogrubioną. Grubość izolacji na przewodach z izolacją standardową (wariant pierwszy) wynosi odpowiednio: DN $32-64,8 \mathrm{~mm}$, DN $100-82,5 \mathrm{~mm}$, DN $300-120,9 \mathrm{~mm}$.

Następnie rozpatrzono straty ciepła na przewodach preizolowanych, gdzie na zasilaniu zastosowano izolację pogrubioną (Plus), na powrocie pozostawiono zaś izolację standardową (Standard). Rozwiązanie to jest droższe od pierwszego wariantu S-S w fazie inwestycyjnej, jednak podczas eksploatacji przynosi dużo więcej korzyści w postaci mniejszych strat ciepła. Grubość izolacji Plus zastosowanej na zasilaniu wynosi odpowiednio: DN $32-79,8 \mathrm{~mm}$, DN 100 - 107,3 mm, DN 300 - 170,5 mm.

Kolejny przypadek izolacji przewodów ciepłowniczych uwzględnia zastosowanie izolacji pogrubionej zarówno na zasilaniu, jak i na powrocie. Rozwiązanie takie daje najlepsze rezultaty w przypadku strat ciepła.

$\mathrm{Z}$ rysunku 4. zawierającego zestawienie strat jednostkowych na przewodach dla trzech rozpatrywanych wariantów grubości izolacji wynika, że najkorzystniejsze wydaje się być rozwiązanie z pogrubioną izolacją na powrocie i zasila- 
niu. Najmniejsza różnica $w$ stratach ciepła jest widoczna przy małych średnicach. Zastosowanie izolacji pogrubionej (wariant drugi P-S) na przewodzie zasilającym DN 32 powoduje zmniejszenie strat jednostkowych o 8,7\%. Pogrubienie izolacji na przewodzie zasilającym DN 100 (wariant drugi P-S) powoduje zmniejszenie jednostkowych strat ciepła o $12,6 \% \mathrm{w}$ stosunku do wariantu pierwszego. Na przewodzie preizolowanym zasilającym DN 300 izolacja została pogrubiona (wariant drugi P-S), co spowodowało zmniejszenie strat przez przenikanie o $18,3 \% \mathrm{w}$ stosunku do izolacji standardowej (wariant pierwszy S-S).

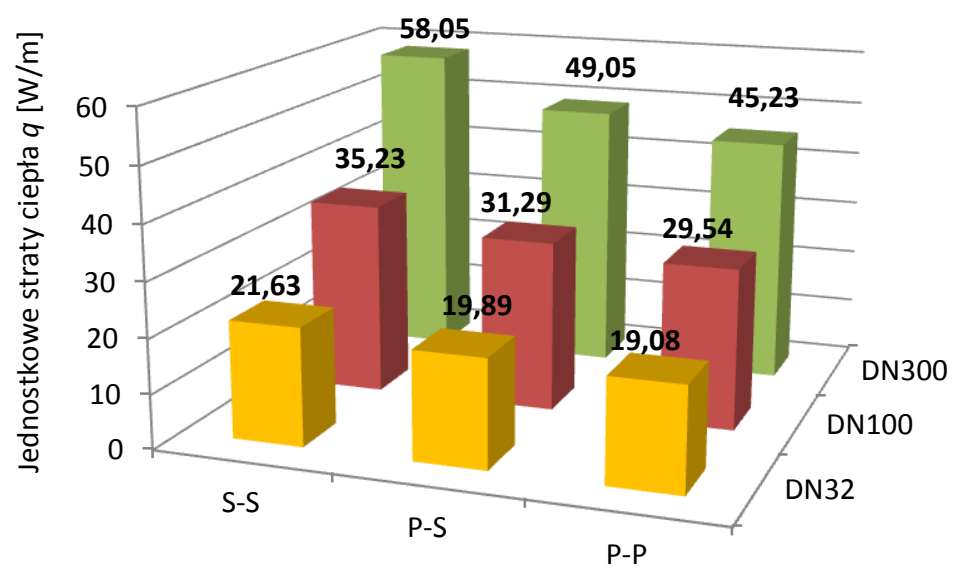

Rys. 4. Zestawienie jednostkowych strat ciepła na przewodach preizolowanych z różnymi grubościami izolacji cieplnej - warianty: 1) S-S, 2) PS, 3) P-P

Stosując pogrubioną izolację na przewodzie DN 32 powrotnym i zasilającym (wariant trzeci P-P), otrzyma się jednostkowe straty ciepła mniejsze o 4,2\% niż w wariancie drugim P-S. Pogrubienie izolacji na przewodzie powrotnym DN 100 zmniejszy jednostkowe straty ciepła o 5,9\% w stosunku do wariantu drugiego P-S. Po zastosowaniu na przewodzie powrotnym DN 300 izolacji pogrubionej (wariant trzeci P-P) zamiast standardowej (wariant drugi P-S) jednostkowe straty ciepła będą mniejsze o $8,4 \%$.

Zastosowanie izolacji pogrubionej (wariant trzeci P-P) zamiast standardowej (wariant pierwszy S-S) na powrocie i zasilaniu dla średnicy DN 32 zmniejsza straty o $13,4 \%$. Stosując przewody zasilające i powrotne DN $100 \mathrm{z}$ pogrubioną izolacją (wariant trzeci P-P), uzyskuje się jednostkowe straty ciepła mniejsze o 19,3\% niż gdyby zastosowano przewody z izolacją standardową (wariant pierwszy S-S). Dla przewodów DN 300 różnica w stratach ciepła dla izolacji S-S (wariant pierwszy) i P-P (wariant drugi) wynosi $28,3 \%$. Średnie jednostkowe 
straty ciepła na przewodach z izolacja P-S są o $6 \%$ większe niż na przewodach z izolacją P-P. Na przewodach z izolacją S-S straty są dużo większe. Różnica wynosi $20 \%$ w stosunku do izolacji P-P i $13 \%$ do izolacji P-S.

Jednostkowe straty ciepła na przewodach sieci ciepłowniczych w zależności od zastosowanego systemu i grubości izolacji cieplnej obrazuje rys. 5. Najefektywniejszy w ograniczaniu strat ciepła jest system rur preizolowanych TwinPipe (wariant czwarty). Z systemu dwóch rur pojedynczych najlepsze efekty daje zastosowanie izolacji pogrubionej na zasilaniu i na powrocie (wariant trzeci). W przypadku przewodu DN 32 system TwinPipe daje lepsze wyniki jednostkowych strat ciepła o $32,5 \%$ w porównaniu z najkorzystniejszym systemem dwóch rur pojedynczych z izolacją P-P, $38 \%-\mathrm{z}$ wariantem drugim P-S i $50 \%-$ z wariantem pierwszym S-S. W przypadku przewodu DN 100 sytuacja jest podobna jak dla przewodu DN 32. Izolacja S-S przewodów DN 100 generuje jednostkowe straty ciepła większe aż o $51 \%$ niż system TwinPipe z izolacją standardową. Najkorzystniejszy z systemów dwóch pojedynczych rur preizolowanych (wariant trzeci P-P) charakteryzuje się jednostkowymi stratami ciepła większymi o 30\% niż w systemie rur TwinPipe. Straty na przewodach preizolowanych z izolacją P-S są o $37 \%$ większe niż na rurach TwinPipe, a na przewodach z izolacją S-S utrata ciepła jest o $50 \%$ większa.

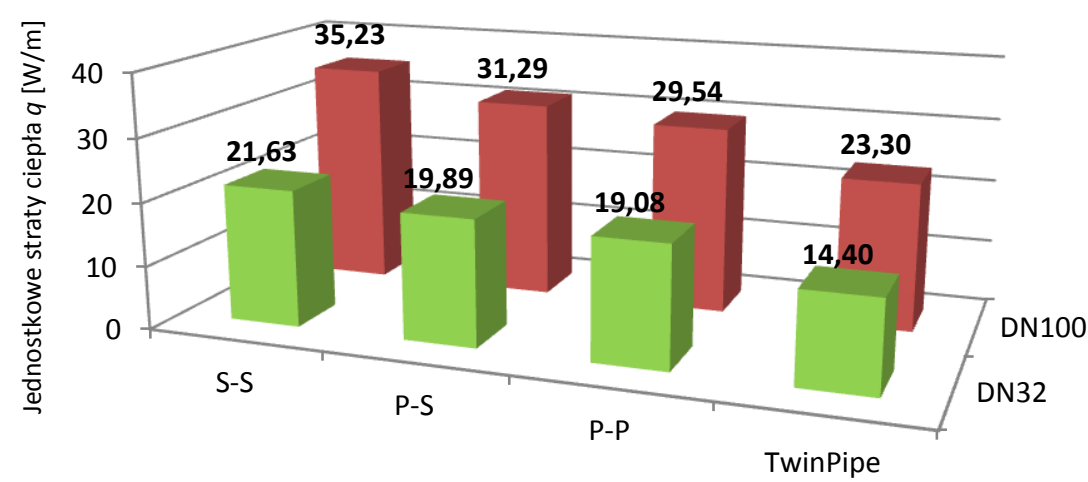

Rys. 5. Zestawienie wyników jednostkowych strat ciepła na przewodach preizolowanych pojedynczych $\mathrm{z}$ różnymi grubościami izolacji cieplnej i TwinPipe (wariant czwarty) - warianty: 1) S-S, 2) P-S, 3) P-P

\section{Podsumowanie}

Tradycyjne systemy rur ciepłowniczych prowadzonych w kanałach zostały wyparte przez nowe systemy rur preizolowanych. System preizolowanych rur ciepłowniczych posiada wiele zalet, m.in.: wytrzymałą izolację odporną na wy- 
sokie temperatury i wnikanie wilgoci. System podziemny nie wymaga kanałów. Systemy rur preizolowanych charakteryzują się małym współczynnikiem przewodzenia ciepła $\lambda$ izolacji cieplnej.

Najbardziej rozpowszechnione i najekonomiczniejsze w fazie inwestycyjnej jest zastosowanie standardowej izolacji na przewodach zasilających i powrotnych sieci cieplnych preizolowanych. Pod względem eksploatacyjnym nie jest to jednak najlepsze rozwiązanie. Standardowa izolacja słabo zabezpiecza przed stratami ciepła, które są o $20 \%$ większe w stosunku do przewodów z pogrubioną izolacją na zasilaniu i powrocie. Najlepsze rezultaty w ograniczaniu strat ciepła $\mathrm{w}$ systemie pary rur pojedynczych osiaga się z zastosowaniem pogrubionej izolacji na przewodach powrotnych i zasilających (wariant trzeci). Gorsze o 6\% efekty w porównaniu $\mathrm{z}$ wariantem trzecim daje zastosowanie izolacji pogrubionej na zasilaniu i standardowej na powrocie. Stosując pogrubioną izolację na zasilaniu, a standardową na powrocie (wariant drugi), otrzyma się różnicę strat mniejszą o $13 \% \mathrm{w}$ stosunku do wariantu pierwszego.

Analiza wykazała, że najlepszym rozwiązaniem pod względem strat ciepła jest system TwinPipe. Stosując ten system, osiaga się efekty lepsze o 50\% $\mathrm{w}$ porównaniu $\mathrm{z}$ systemem pary rur pojedynczych $\mathrm{z}$ izolacją standardową i o 37\% lepsze w porównaniu z izolacją P-S. Mimo wielu zalet, system TwinPipe jest mało popularny w Polsce ze względu na ograniczony zakres średnic od DN 20 do DN 150 i trudności z podłączeniem do stosowanego systemu pary rur pojedynczych. Jego przyjęcie wymaga jednak przeprowadzenia szczegółowej analizy ekonomicznej zasadności stosowania.

\section{Literatura}

[1] Iwko I.: Sposoby ograniczania strat ciepła w sieciach ciepłowniczych w aspekcie stosowania rur preizolowanych o różnych rodzajach izolacji. Instal, nr 9/2007, s. $48-55$.

[2] Szkarowski A., Łatowski L.: Ciepłownictwo. Wydawnictwo Naukowo-Techniczne, Warszawa 2006.

[3] Szulc W., Uznański P.: Sieci ciepłownicze preizolowane - spokój do emerytury czy bomba zegarowa? Instal, $\mathrm{nr}$ 2/2009, s. 20-24.

[4] Falba Ł., Pietrzyk Z., Smyk A.: Wykorzystanie MES do obliczania strat ciepła w miejskiej sieci ciepłowniczej. Ciepłownictwo, Ogrzewnictwo, Wentylacja, nr 3/2009, s. 8-13.

[5] PN-EN 253: 2009. Sieci ciepłownicze - System preizolowanych rur do wodnych sieci ciepłowniczych układanych bezpośrednio w gruncie - Zespół ze stalowej rury przewodowej, izolacji cieplnej z poliuretanu i płaszcza osłonowego z polietylenu.

[6] http://www.logstor.com/showpage.php?pageid=2135978.

[7] PN-EN 13941: 2009. Projektowanie i budowa sieci ciepłowniczych z systemu preizolowanych rur zespolonych.

[8] PN-EN 15698 - 1: 2009. Sieci ciepłownicze - System preizolowanych rur zespolonych do wodnych sieci ciepłowniczych układanych bezpośrednio $\mathrm{w}$ gruncie 
- Część 1: Zespół dwururowy ze stalowej rury przewodowej, izolacji cieplnej z poliuretanu i płaszcza osłonowego z polietylenu.

[9] Iwko I.: Obliczenia strat ciepła podziemnych preizolowanych sieci ciepłowniczych. Instal, nr 11/2009, s. 12-15.

\section{HEAT LOSSES IN THE PREINSULATED DISTRICT HEATING SYSTEMS}

S u m m a r y

The article presents the analysis of unit heat losses through the penetration of the preinsulated district heating systems. The unit heat losses have been calculated for the three most commonly used variants of the isolation system of the pair of single pipes and TwinPipe system. Comparison has been made of the total losses in the considered options.

Keywords: variants of the isolation system and comparative analysis, heat loss unit, preinsulated pipes

DOI: $10.7862 / \mathrm{rb} .2012 .1$ 